\title{
Effects of Working Hours on the Life of Post Graduate Residents and on Patient Care
}

\author{
Qamar Mehboob, Waqar Arif, Muhammad Arif, Muhammad Saqlain, Sana Arif, Amina Javaid Malik
}

\section{ABSTRACT}

Background: Despite a lot of research regarding postgraduate residents (PGRs) duty hours, its benefits are still controversial. There is a constant need for further evaluation. So, we conducted the present research work to update a systematic review of the literature on duty hour restrictions. Objective: To evaluate the effects of the 80-hour postgraduate trainees work per week, restrictions on patient safety, resident well-being, and resident education. Study Design: Cross-Sectional Survey. Settings: Allied Hospital, Faisalabad Pakistan. Duration: One year from, Jan 2018 - Jan 2019. Methodology: A 15 item structured questionnaire based upon 5-point Likert scale was developed. The participants were 130 including males \& females. Results: Residents reported per week working hours a mean of $103 \pm 0.31$, certainly more than 80-hours limit recommended by Accreditation Council for Graduate Medical Education (ACGME). Among all, 78\% respondents reported that sleep deprivation had negatively affected their duty. A strong majority of senior PGs ( $88 \%)$, as compared to juniors $(72 \%)$, believed that work hour limits would have markedly improved effect on patient care and somewhat improve the work life (juniors $69 \%$ \& seniors $65 \%$ ). $89 \%$ seniors suggested marked improvement in personal life after work hour limits while 55\% juniors believed a somewhat improvement. Conclusion: Present PGRs duty hour changes are insufficient to improve resident well-being and have negative effects on patient outcomes and performance. Greater flexibility regarding their training requirements, is the need of the day.

Keywords: Work hours, Patient care.

Corresponding Author Submitted for Publication: 19-10-2019 Accepted for Publication: 22-01-2020

DR. QAMAR MEHBOOB, Associate Professor, Physiology, Faisalabad Medical University, Faisalabad-Pakistan Contact / Email: +92 313-4458720, qamarmehboob89@yahoo.com

Citation: Mehboob Q, Arif W, Arif M, Saqlain M, Arif S, Malik AJ. Effects of Work Hours on Post Graduate Resident's Life and Patient Care. APMC $2020 ; 14(1): 41-5$

\section{INTRODUCTION}

In Pakistan, the total number of registered doctors is increasing day by day. During 2011-12 to 2014-15, with a $13 \%$ increase, the total number of $1,75,223$ doctors were registered. Similarly, in 2011-12, 11,649 dentists were registered. But now with an increase of 23 percent, the total number of registered dentists has become 15,106. Postgraduate residents (PGRs) have also remarkable record. In 1947, only seven medical specialists were present which became eighteen thousand in $2007 .^{1}$

This huge number of PGRs is getting training and qualification within Pakistan. In 2006, there were 9,036 applicants for FCPS Part I exam, with an average pass rate of $20 \%$. The number of candidates is increasing rapidly and it is reported that in 2016 it reached to 18,540 who wanted to enter the College training program. However, among them, only 5,100 were qualified. For FCPS II, a total of 4,707 candidates appeared in viva and only 1,521 cleared it. The pass percentage was almost $30 \%$ and many of them were repeaters. Internationally, a pass percentage less than $40 \%$ is considered poor. ${ }^{2}$

One must think that an examination with such a low pass percentage needs review. Either the exam is conducted wrongly, or the students are not fully prepared for it. So, there is a great need to improve the training programs and bring them to international standards. To achieve this goal, we should develop our formative assessments and for which, the best place is where the trainee is being trained.

In many countries, the postgraduate medical training programs are reviewed regularly specially in the United Kingdom ${ }^{1,3}$ for the betterment of patients' care and also to motivate assessment of present practice in other countries, especially having British systems. In 2003, Accreditation Council for Graduate Medical Education (ACGME) made some changes in resident duty hours and implemented the first complete and detailed resident work hour regulations nationwide. ${ }^{4}$

After an unfortunate death of a young lady named Libby Zion in a New York Hospital, resident duty hour (RDH) restrictions were implemented in the country. When the matter was fully investigated, it was found that resident's fatigue was one of the contributing factors. In July 2003, the Accreditation Council for Graduate Medical Education (ACGME) implemented a 4-week period with an 80-hour duty limit on residents followed by, in 2011, a 16-hour duty period for first year postgraduate residents (PGY1). ${ }^{5}$

In 2012, the province of Quebec recommended 16-hour periods for residents. The objective of duty hour limitations was not only the betterment of patient care, but also to improve residents' well-being, and education. ${ }^{6}$ With the decreased duty hours, the impact on training time could have a negative effect on educational and patient care especially in surgical disciplines. ${ }^{5,7}$ A "fixed duty hours" approach to all residents may not be appropriate because of variations in training needs, practice patterns and other requirements of various disciplines. ${ }^{8}$

After the implementation of progressive work-hour restrictions to $P G$ training by ACGME, it became greatly controversial. ${ }^{9-12}$ Reports in favor of this stated that in surgical subspecialties, there was an improvement in patient care, while opponents claimed that it jeopardized their education and training for independent surgical practice. ${ }^{13-15}$ In modern surgical training, 
the contraction in resident work hours may be one of the greatest challenges. Usually, during surgical residency, long duty hours were assumed better for both competency and patient safety. During their long stay, residents might observe patients throughout their hospital stay and managed pre-, intra and post-operative treatment. ${ }^{16}$ By keeping a continued eye over the patients, different medical errors can also be prevented. Even today, the impact or effect of implementation of work-hour restrictions, on patient safety, remained controversial.

PGRs, especially of the surgical department, are mostly affected by these changes. There is a great need to rule out the effects of these changes. To evaluate the effects of the 80-hour postgraduate trainees work week restrictions on patient safety, resident well-being, and resident education, we conducted a research project based on 15 items structured questionnaire.

\section{METHODOLOGY}

Settings: Allied Hospital, Faisalabad Pakistan.

Duration: 1 year (Jan, 2018 - Jan, 2019).

Sample Technique: Convenient sampling technique.

Sample Size: 130 participations.

Inclusion Criteria: Male \& female, married/unmarried, PGRs from 1 st to 4 th/5th year.

Exclusion Criteria: House officers, medical officers, PGRs with any family problem which can affect their working at hospital.

Methods: We conducted a research project consisting 15 items structured questionnaire based upon five-point Likert scales. 130 (Surgical \& allied) PG residents of Allied Hospital, Faisalabad were approached for the study. We divided the participants into 2 groups. We include $1^{\text {st }}$ and $2^{\text {nd }}$ year residents in 1st group (PGY1 \& 2) and $3^{\text {rd }}$, $4^{\text {th }}$ and $5^{\text {th }}$ year PGRs in 2 nd group. Both groups include married as well as unmarried participants. Informed consent was obtained. The data was collected and arranged in tabulated form. The results were analyzed statistically. Correlation was considered significant at the 0.01 level (2-tailed).

\section{RESULTS}

Total 130 PGRs were approached. Of these respondents, $63.84 \%$ were juniors (PGY1 \& 2) and 25.38 were females (Table-1). The mean age of participants was $27.33 \pm 1.71$ years. Out of them, $30 \%$ were married and $70 \%$ were unmarried. According to our data, $38 \%$ of the respondents were working for 91-100 hours per week and 33\% for 101-110 hours per week. The mean working hours/ week was $103 \pm 0.31$. In contrast the respondents' ideal work hours mean was $84 \pm 0.11$ hours per week. The average call frequency was every $5^{\text {th }}$ day, as reported by $54 \%$ of respondents.

Description of the ideal working hours

\begin{tabular}{|c|c|c|c|c|c|}
\hline & N & Minimum & Maximum & Mean & Std. Deviation \\
\hline IWH & 130 & 30.00 & 81.00 & 38.8308 & 8.11176 \\
\hline Valid N (listwise) & 130 & & & & \\
\hline
\end{tabular}

IWH: Ideal Work Hours
Study Design: Cross-Sectional Survey.

Table 1: Various sample characteristics ( $n=130)$

\begin{tabular}{|c|c|c|c|}
\hline & Characteristic & $\mathbf{N}$ & $\%$ \\
\hline \multirow{5}{*}{ Clinical PGY } & 1 & 31 & 23.84 \\
\hline & 2 & 49 & 37.69 \\
\hline & 3 & 19 & 14.6 \\
\hline & 4 & 30 & 23.07 \\
\hline & 5 & 11 & 8.46 \\
\hline \multirow{3}{*}{ Age in Years } & $<25$ & 9 & 6.92 \\
\hline & $25-30$ & 114 & 87.69 \\
\hline & $>30$ & 7 & 5.38 \\
\hline \multirow{2}{*}{ Gender } & Male & 97 & 74.61 \\
\hline & Female & 33 & 25.38 \\
\hline \multirow{2}{*}{ Marital Status } & Single & 91 & 70 \\
\hline & Married & 39 & 30 \\
\hline \multirow{5}{*}{ Duty hours/ Week } & $<80$ & 3 & 2.30 \\
\hline & $81-90$ & 27 & 20.76 \\
\hline & $91-100$ & 49 & 37.69 \\
\hline & $101-110$ & 43 & 33.07 \\
\hline & $>110$ & 8 & 6.15 \\
\hline \multirow{5}{*}{$\begin{array}{l}\text { Ideal work hours } \\
\text { according to you }\end{array}$} & $<80$ & 39 & 30 \\
\hline & $81-90$ & 86 & 66.15 \\
\hline & $91-100$ & 1 & 0.76 \\
\hline & $101-110$ & 2 & 1.53 \\
\hline & $>110$ & 2 & 1.53 \\
\hline \multirow{5}{*}{$\begin{array}{l}\text { Average call } \\
\text { frequency }\end{array}$} & Every day & 0 & 0 \\
\hline & Every $2^{\text {nd }}$ day & 0 & 0 \\
\hline & Every $3^{\text {rd }}$ day & 46 & 35.38 \\
\hline & Every $4^{\text {th }}$ day & 14 & 10.76 \\
\hline & Every $5^{\text {th }}$ day & 70 & 53.84 \\
\hline
\end{tabular}

Table 2: Survey responses: Satisfaction \& perceptions of work environment $(n=130)$

\begin{tabular}{|l|l|c|c|}
\hline Response & $\mathbf{n}$ & $\%$ \\
\hline \multirow{4}{*}{$\begin{array}{l}\text { Sleep deprivation } \\
\text { has negatively } \\
\text { affected work }\end{array}$} & Strongly agree & 102 & 78.46 \\
\cline { 2 - 4 } & Somewhat agree & 19 & 14.61 \\
\cline { 2 - 4 } & Disagree & 6 & 4.61 \\
\cline { 2 - 4 } & Somewhat disagree & 2 & 1.53 \\
\cline { 2 - 4 } & Strongly disagree & 1 & 0.76 \\
\hline \multirow{4}{*}{$\begin{array}{l}\text { Work environment } \\
\text { is abusive }\end{array}$} & Strongly agree & 1 & 0.76 \\
\cline { 2 - 4 } & Somewhat agree & 80 & 61.53 \\
\cline { 2 - 4 } & Disagree & 20 & 15.38 \\
\cline { 2 - 4 } & Somewhat disagree & 30 & 23.07 \\
\cline { 2 - 4 } & Strongly disagree & 0 & 0 \\
\hline \multirow{4}{*}{$\begin{array}{l}\text { Have you seriously } \\
\text { considered quitting }\end{array}$} & Strongly agree & 0 & 0 \\
\cline { 2 - 4 } cargical/medical & Somewhat agree & 63 & 48.46 \\
\cline { 2 - 4 } & Disagree & 9 & 6.92 \\
\cline { 2 - 4 } & Somewhat disagree & 11 & 8.46 \\
\cline { 2 - 4 } & Strongly disagree & 47 & 36.15 \\
\hline \multirow{3}{*}{$\begin{array}{l}\text { Are you satisfied } \\
\text { with your residency } \\
\text { training? }\end{array}$} & Strongly agree & 7 & 5.38 \\
\cline { 2 - 4 } & Somewhat agree & 55 & 42.30 \\
\cline { 2 - 4 } & Disagree & 47 & 36.15 \\
\cline { 2 - 4 } & Somewhat disagree & 21 & 16.15 \\
\cline { 2 - 4 } & Strongly disagree & 0 & 0 \\
\hline \multirow{3}{*}{$\begin{array}{l}\text { Would you choose } \\
\text { surgical/medical } \\
\text { career again? }\end{array}$} & Strongly agree & 66 & 50.76 \\
\cline { 2 - 4 } & Somewhat agree & 14 & 10.76 \\
\cline { 2 - 4 } & Disagree & 19 & 14.61 \\
\cline { 2 - 4 } & Somewhat disagree & 20 & 15.38 \\
\cline { 2 - 4 } & Strongly disagree & 11 & 8.46 \\
\hline
\end{tabular}


According to our research, $78 \%$ of the participants reported that sleep deprivation has negatively affected their work (Table-2). A total of $42 \%$ of respondents were being satisfied with their residency training while $48 \%$ were seriously considered quitting surgical/medical career. 51\% reported that they would choose surgical/medical career again.

The majority (97\%) of participants strongly believed that anticipated effects of restrictions on resident work hour improved their personal life. With regard to the quality of resident work $93 \%$ believed that it would has positive effect while few (1.5) had opposite thought that such type of restrictions either somewhat or strongly deteriorates their work life.

Table 3: Anticipated effects of restrictions on resident work hour

\begin{tabular}{|c|c|c|c|}
\hline Effect & $\begin{array}{c}\text { On patient } \\
\text { care }\end{array}$ & $\begin{array}{c}\text { On resident } \\
\text { work life }\end{array}$ & $\begin{array}{c}\text { On resident } \\
\text { personal life }\end{array}$ \\
\hline $\begin{array}{c}\text { Markedly } \\
\text { improved }\end{array}$ & $59.23 \%$ & $52.30 \%$ & $57.69 \%$ \\
\hline $\begin{array}{c}\text { Somewhat } \\
\text { improved }\end{array}$ & $31.53 \%$ & $40.76 \%$ & $39.23 \%$ \\
\hline No effect & $5.38 \%$ & $5.38 \%$ & $0.76 \%$ \\
\hline $\begin{array}{c}\text { Somewhat } \\
\text { deteriorate }\end{array}$ & $1.53 \%$ & $0.76 \%$ & $1.53 \%$ \\
\hline $\begin{array}{c}\text { Markedly } \\
\text { deteriorate }\end{array}$ & $2.30 \%$ & $0.76 \%$ & $0.76 \%$ \\
\hline
\end{tabular}

Table 4: Effects on resident's health

\begin{tabular}{|l|l|c|c|}
\hline Response & N & $\%$ \\
\hline \multirow{4}{*}{$\begin{array}{l}\text { Proper diet } \\
\text { intake during } \\
\text { work hours }\end{array}$} & Strongly agree & 11 & 8.46 \\
\cline { 2 - 4 } & Somewhat agree & 42 & 32.30 \\
\cline { 2 - 4 } & Disagree & 2 & 1.53 \\
\cline { 2 - 4 } & Somewhat disagree & 31 & 23.84 \\
\cline { 2 - 4 } & strongly disagree & 44 & 33.84 \\
\hline \multirow{4}{*}{$\begin{array}{l}\text { Regular bowl } \\
\text { habits }\end{array}$} & Strongly regular & 6 & 4.61 \\
\cline { 2 - 4 } & Somewhat regular & 39 & 30 \\
\cline { 2 - 4 } & Irregular & 7 & 5.38 \\
\cline { 2 - 4 } & Somewhat irregular & 42 & 32.30 \\
\cline { 2 - 4 } & Strongly irregular & 36 & 27.69 \\
\hline \multirow{4}{*}{$\begin{array}{l}\text { Time for studies } \\
\text { during training }\end{array}$} & Strongly agree & 2 & 1.53 \\
\cline { 2 - 4 } & Somewhat agree & 43 & 33.07 \\
\cline { 2 - 4 } & Disagree & 19 & 14.61 \\
\cline { 2 - 4 } & Somewhat disagree & 25 & 19.23 \\
\cline { 2 - 4 } & Strongly disagree & 41 & 31.53 \\
\hline \multirow{4}{*}{$\begin{array}{l}\text { Giving proper } \\
\text { time to your } \\
\text { family }\end{array}$} & Never & 17 & 13.07 \\
\cline { 2 - 4 } & Rarely & 89 & 68.46 \\
\cline { 2 - 4 } & Sometimes & 17 & 13.07 \\
\cline { 2 - 4 } & Often & 5 & 3.84 \\
\cline { 2 - 4 } & All of the time & 2 & 1.53 \\
\hline
\end{tabular}

During our research, we also did a comparison between juniors and seniors opinion. $88 \%$ of seniors and $72 \%$ of juniors were agreed that work hour limits markedly improved the patient care. Duty hours of senior and junior trainees were compared statistically.

Most residents, either junior or senior, reported that work hour limitations would have marked beneficial impact on their work life.

Table 5: Comparison of Junior and Senior PGRs

\begin{tabular}{|c|c|c|c|}
\hline & Juniors & Seniors \\
\hline \multirow{2}{*}{$\begin{array}{l}\text { Work hour limits } \\
\text { would have impact } \\
\text { on patient care }\end{array}$} & Markedly improved & $72 \%$ & $88 \%$ \\
\hline & $\begin{array}{l}\text { Somewhat } \\
\text { improved }\end{array}$ & $28 \%$ & $12 \%$ \\
\hline \multirow{2}{*}{$\begin{array}{l}\text { Work hour limits } \\
\text { would have impact } \\
\text { on work life }\end{array}$} & Markedly imp & $31 \%$ & $35 \%$ \\
\hline & $\begin{array}{l}\text { Somewhat } \\
\text { improved }\end{array}$ & $69 \%$ & $65 \%$ \\
\hline \multirow{2}{*}{$\begin{array}{l}\text { Work hour limits } \\
\text { would have impact } \\
\text { on personal life }\end{array}$} & Markedly imp & $45 \%$ & $89 \%$ \\
\hline & $\begin{array}{l}\text { Somewhat } \\
\text { improved }\end{array}$ & $55 \%$ & $11 \%$ \\
\hline
\end{tabular}

Table 6: Duty hours per week

Descriptive Statistics

\begin{tabular}{|c|c|c|c|c|c|}
\hline & $\mathbf{N}$ & Minimum Maximum & Mean & $\begin{array}{c}\text { Std. } \\
\text { Deviation }\end{array}$ \\
\hline Juniors & 83 & 18.50 & 100.00 & 54.0361 & 11.11162 \\
\hline $\begin{array}{c}\text { Valid N } \\
\text { (listwise) }\end{array}$ & 83 & & & & \\
\hline
\end{tabular}

Descriptive Statistics

\begin{tabular}{|c|c|c|c|c|c|}
\hline & $\mathbf{N}$ & Minimum & Maximum & Mean & $\begin{array}{c}\text { Std. } \\
\text { Deviation }\end{array}$ \\
\hline Juniors & 83 & 18.50 & 100.00 & 54.0361 & 11.11162 \\
\hline Seniors & 47 & 18.50 & 100.00 & 58.0957 & 15.86891 \\
\hline $\begin{array}{c}\text { Valid N } \\
\text { (listwise) }\end{array}$ & 47 & & & & \\
\hline
\end{tabular}

One-Sample Statistics

\begin{tabular}{|c|c|c|c|c|}
\hline & $\mathbf{N}$ & Mean & Std. Deviation & Std. Error Mean \\
\hline Juniors & 83 & 54.0361 & 11.11162 & 1.21966 \\
\hline Seniors & 47 & 58.0957 & 15.86891 & 2.31472 \\
\hline
\end{tabular}

One-Sample Test

\begin{tabular}{|c|c|c|c|c|c|c|}
\hline & \multicolumn{6}{|c|}{ Test Value $=0$} \\
\hline & \multirow[t]{2}{*}{$t$} & \multirow[t]{2}{*}{$\mathrm{df}$} & \multirow{2}{*}{$\begin{array}{l}\text { Sig. (2- } \\
\text { tailed) }\end{array}$} & \multirow{2}{*}{$\begin{array}{c}\text { Mean } \\
\text { Difference }\end{array}$} & \multicolumn{2}{|c|}{$\begin{array}{c}95 \% \text { Confidence Interval } \\
\text { of the Difference }\end{array}$} \\
\hline & & & & & Lower & Upper \\
\hline Juniors & 44.304 & 82 & .000 & 54.03614 & 51.6099 & 56.4624 \\
\hline Seniors & 25.098 & 46 & .000 & 58.09574 & 53.4365 & 62.7550 \\
\hline
\end{tabular}

Correlations

\begin{tabular}{|c|c|c|c|}
\hline \multirow{3}{*}{ Juniors } & Juniors & Seniors \\
\cline { 2 - 4 } & Pearson Correlation & 1 & $.737^{* *}$ \\
\cline { 2 - 4 } & Sig. (2-tailed) & & .000 \\
\hline \multirow{3}{*}{ Seniors } & $\mathbf{N}$ & 83 & 47 \\
\cline { 2 - 4 } & Pearson Correlation & $.737^{* *}$ & 1 \\
\cline { 2 - 4 } & Sig. (2-tailed) & .000 & \\
\cline { 2 - 4 } & $\mathbf{N}$ & 47 & 47 \\
\hline$*$. Correlation is significant at the 0.01 level (2-tailed). \\
\hline \multirow{3}{*}{}
\end{tabular}




\section{DISCUSSION}

Health is a national responsibility. There is a great need for training programs for PGs at national as well as provincial level. Furthermore, a long-term plan should be developed to emulate the condition in Australia and UK where completion of training is compulsory even for family/general practitioners ${ }^{1}$. In Pakistan, social security support of people needing health care is poorly developed. Although the systems of PG training in Pakistan are well grounded and future prospects are good yet efforts should be made to develop medical career more effective and more attractive.

According to our research, there was an overall improvement in PGs quality of life and we found similar results as reported by many other researchers. ${ }^{17-21}$ Previously, in 2002, it was reported that PGs, especially in surgical field, were working for greater hours per week than the 80-hour limit applied by ACGME requirements. In our study, we found the same results with a positive effect on resident quality of life and on patient care.

In 2011, ACGME, in its four-week period,22 revised the guidelines for resident duty hours and limited these to 80 hours per week. To improve their working abilities, residents must be provided with one day in seven free from all educational and clinical responsibilities, averaged over a four-week period, inclusive of call. Adequate time for rest and personal activities must be provided. This should consist of a 10 -hour time period provided between all daily duty periods and after in-house call. Rathore FA also recommended that sufficient time should be provided to PGs for rest and personal activities. Furthermore, he proposed that hospital administration should also facilitate these residents during their on-call duties. ${ }^{22}$ We found similar results in our research. With the limited duty hours, there was marked improvement of PGs personal life especially for seniors $89 \%$ as compared to juniors, $45 \%$.

According to PMDC criteria, with a 10-hour rest period, in-house call must occur no more frequently than every third night ${ }^{23}$. In our research, we found that most of PGs (54\%) recommended every $5^{\text {th }}$ day on call duty while few $(35 \%)$ supported PMDC recommendations.

In a report forwarded by Ahmed (2014), 5 it was stated that recent resident hour changes had not improved resident wellbeing with a negative effect on patient care. He recommended greater flexibility to accommodate resident training. Further research regarding the outcomes of work hour limitations might be beneficial. ${ }^{13}$

During the academic year 2001-2002, in a combined effort of residency program directors of National Graduate Medical Education Census, American Medical Association and Association of American Medical College, it was reported that surgery residents were found to have 78.9 average weekly onduty hours ${ }^{24}$ while reported by general surgery residency program directors, residents worked 91 hours per week. ${ }^{25} \mathrm{~A}$ survey of gynecological residents conducted in 2000, reported working hours were 80 hours / week (42\% residents) with $77 \%$ residents who reported desiring work hour limitations. ${ }^{26}$ In our research, we found that in present circumstances, only $42 \%$
PGs were satisfied with their residency training while $36 \%$ disagreed.

For the evaluation of outcomes of work hour limitationcompliance strategies on PGs, we hope that our data will serve as a baseline. In a series of resident work hour reform measures, ACGME requirements might be the first wave. Many researchers reported that ACGME requirements are not enough. ${ }^{27}$

\section{CONCLUSION}

Current PGRs duty hour changes are insufficient to improve resident wellbeing and have negative effects on patient outcomes and performance. Greater flexibility regarding their training requirements is the need of the day.

\section{LIMITATIONS}

The study is done in one setting only. Nationwide sample collection can change the outcome.

\section{SUGGESTIONS / RECOMMENDATIONS}

We suggest that more and more surgical residency programs should be introduced to ensure education of PGRs. Work hours of residents should be reduced which will improve their health as well as it will be helpful in provision of high-quality patient care.

\section{CONFLICT OF INTEREST / DISCLOSURE}

The author certify that they have no affiliations with or involvement in any organization or entity with any financial or non-financial interest in the subject matter.

\section{ACKNOWLEDGEMENTS}

we are highly thankful Prof. Dr. Sajid Sheik, HOD, S2, Allied hospital and Prof. Dr. Ashraf Cheema, HOD Burn and Reconstructive Surgery, Allied Hospital Faisalabad Pakistan for their cooperation and guideline to conduct this research project.

\section{REFERENCES}

1. Biggs JS. Postgraduate medical training in Pakistan: observations and recommendations. J Coll Physicians Surg Pak. 2008;18(1):58-63.

2. President addresses 13 reconstituted faculties - CPSP https://www.cpsp.edu.pk/bulletin/generate_pdf?view_pdf=aguideline-to-faculties

3. Craft A. Modernizing medical careers: a response from the Academy of Medical Royal Colleges. J R Soc Med. 2006;99(4):165-7.

4. Whang EE, Perez A, Ito H, Mello MM, Ashley SW, Zinner MJ. Work hours reform: perceptions and desires of contemporary surgical residents. J Am Coll Surg. 2003;197(4):624-30.

5. Ahmed N, Devitt KS, Keshet I, Spicer J, Imrie K, Feldman L, et al. A systematic review of the effects of resident duty hour restrictions in surgery: impact on resident wellness, training, and patient outcomes. Ann Surg. 2014;259(6):1041-53.

6. Nasca. An Open Letter to the GME Community. Chicago, IL: Accreditation Council for Graduate Medical Education; 2016:1-6. 
7. Lambert TW, Smith F, Goldacre MJ. The impact of the European Working Time Directive 10 years on: views of the UK medical graduates of 2002 surveyed in 2013-2014. JRSM Open. 2016;7(3):2054270416632703.

8. Drolet BC, Sangisetty S, Tracy TF, Cioffi WG. Surgical residents' perceptions of 2011 Accreditation Council for Graduate Medical Education duty hour regulations. JAMA Surg. 2013;148(5):42733.

9. Harris JD, Staheli G, LeClere L, Andersone D, McCormick F. What effects have resident work-hour changes had on education, quality of life, and safety? A systematic review. Clin Orthop Relat Res. 2015;473(5):1600-8.

10. Peets A, Ayas NT. Restricting resident work hours: the good, the bad, and the ugly. Crit Care Med. 2012;40(3):960-6.

11. Pellegrini VD Jr. Perspective: ten thousand hours to patient safety, sooner or later. Acad Med. 2012;87(2):164-7.

12. Sen S, Kranzler HR, Didwania AK, Schwartz AC, Amarnath S, Kolars JC, et al. Effects of the 2011 duty hour reforms on interns and their patients: a prospective longitudinal cohort study. JAMA Intern Med. 2013;173(8):657-62.

13. Jamal MH, Wong S, Whalen TV. Effects of the reduction of surgical residents' work hours and implications for surgical residency programs: a narrative review. BMC Med Educ. 2014;14(1):14.

14. Froelich J, Milbrandt JC, Allan DG. Impact of the 80-hour workweek on surgical exposure and national in-training examination scores in an orthopedic residency program. J Surg Educ. 2009;66(2):85-8.

15. Fried GM, Derossis AM, Bothwell J, Sigmann HH. Comparison of laparoscopic performance in vivo with performance measured in a laparoscopic simulator. Surg Endosc. 1999;13(11):1077-81.

16. Britt LD, Sachdeva AK, Healy GB, Whalen TV, Blair PG. Resident duty hours in surgery for ensuring patient safety, providing optimum resident education and training, and promoting resident well-being: a response from the American College of Surgeons to the Report of the Institute of Medicine, "Resident Duty Hours:
Enhancing Sleep, Supervision, and Safety". Surgery. 2009;146(3):398-409.

17. Hutter MM, Kellogg KC, Ferguson CM, Abbott WM, Warshaw AL. The impact of the 80-hour resident workweek on surgical residents and attending surgeons. Ann Surg. 2006;243(6):86471.

18. Whang EE, Mello MM, Ashley SW, Zinner MJ. Implementing resident work hour limitations: lessons from the New York State experience. Ann Surg. 2003;237(4):449-55.

19. Irani JL, Mello MM, Ashley SW, Whang EE, Zinner MJ, Breen E. Surgical residents' perceptions of the effects of the ACGME duty hour requirements 1 year after implementation. Surgery. 2005;138(2):246-53.

20. Fletcher KE, Underwood W 3rd, Davis SQ, Mangrulkar RS, McMahon LF Jr, Saint S. Effects of work hour reduction on residents' lives: a systematic review. JAMA. 2005;294(9):1088100.

21. Barden CB, Specht MC, McCarter MD, Daly JM, Fahey TJ 3rd. Effects of limited work hours on surgical training. J Am Coll Surg. 2002;195(4):531-8.

22. Rathore FA, Farooq F. Going beyond the resident duty hours in Pakistan. J Pak Med Assoc. 2012;62(2):189-90.

23. Pakistan Medical \& Dental Council Postgraduate Medical and Dental Education Regulations, 8th May 2010. http://pmdc.org.pk/LinkClick.aspx?fileticket=nL5x/TDFA/4\%3D.

24. Brotherton SE, Simon FA, Etzel SI. US graduate medical education, 2001-2002: changing dynamics. JAMA. 2002;288(9):1073-8.

25. Cochran A, Melby S, Foy HM, Wallack MK, Neumayer LA. The state of general surgery residency in the United States: program director perspectives, 2001. Arch Surg. 2002;137(11):1262-5.

26. Deidre M Defoe, Michael L Power, Gerald B Holzman et al. Long hours and little sleep: work schedules of residents in obstetrics and gynecology. Obstet Gynecol. 2001;97(6):1015-8.

27. Steinbrook R. The Debate over Residents' Work Hours. N Engl J Med. 2002;347(16):1296-302.

\section{AUTHORSHIP AND CONTRIBUTION DECLARATION}

\section{AUTHORS}

Dr. Qamar Mehboob

Associate Professor, Physiology

Faisalabad Medical University, Faisalabad Pakistan

\section{Dr. Waqar Arif}

Post Graduate Resident, Burn \& Reconstructive Surgery

Allied Hospital, Faisalabad Pakistan

\section{Dr. Muhammad Arif}

Associate Professor, Ophthalmology

Faisalabad Medical University, Faisalabad Pakistan

\section{Dr. Muhammad Saqlain}

Post Graduate Resident, Neurosurgery

Lahore General Hospital, Lahore Pakistan

\section{Dr. Sana Arif}

Final Year MBBS Student

Shaikh Zayed Medical College, Rahim Yar Khan Pakistan

\section{Dr. Amina Javaid Malik \\ Ex-House Officer, University Medical Complex \& Research \\ Centre University of Sargodha, Sargodha Pakistan}

Contribution to The Paper

Signatures

Data Collection

Data Collection

Statistical Analysis

Performa \& Likert Scale Formation

Performa \& Likert Scale Formation

Interpretation

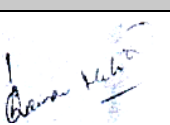

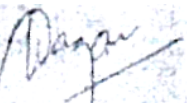

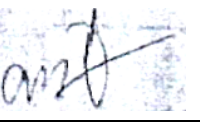

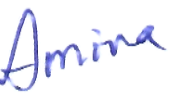

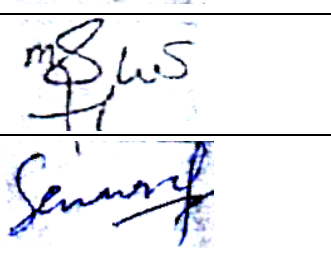

